\title{
Organocatalyzed Ring-Opening Polymerization of Cyclic Lysine Derivative: Sustainable Access to Cationic Poly( $\varepsilon$-lysine) Mimics
}

Jinlong Chen, ${ }^{\dagger}$ Yilin Dong, ${ }^{\dagger}$ Chunsheng Xiao, Youhua Tao, ${ }^{*}$ Xianhong Wang

Key Laboratory of Polymer Ecomaterials, Changchun Institute of Applied Chemistry, Chinese Academy of Sciences, Renmin Street 5625, Changchun 130022, People's Republic of China. 


\section{Catalogue}

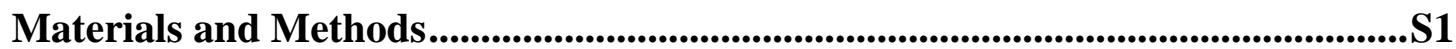

Synthesis of Dimethyl-ProtectedCyclic Lysine.........................................................S1

Synthesis of $N$-Benzoyl- $\alpha$-Dimethylamino- $\varepsilon$-Caprolactam.............................................S2

General Polymerization Procedure ..........................................................................S2

General Procedure for Synthesis of Poly( $\varepsilon$-lysine $)$ Mimics ....................................S2

Antimicrobial Assay

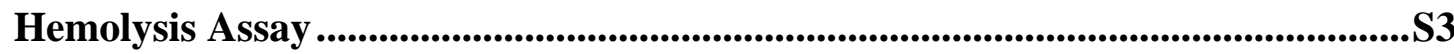

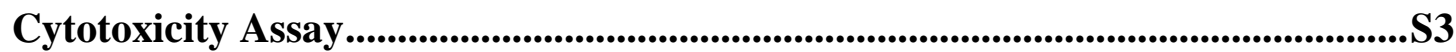

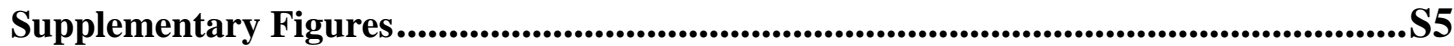

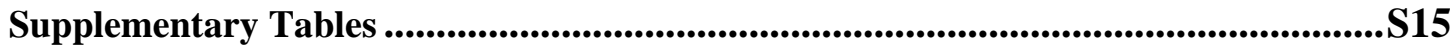

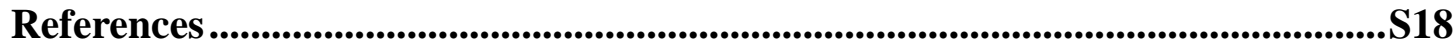




\section{Materials and Methods}

L-lysine monohydrochloride (99\%) were Xi'an Dafengshou Biotechnology Co. Ltd. $t$-BuP and $\mathrm{Pd} / \mathrm{C}$ (10\% Pd on Carbon, wetted with ca. 55\% Water) were obtained from Energy Chemical. $N, N$-Dimethylacetamide (DMAC) were freshly distilled from $\mathrm{CaH}_{2}$. All the other solvents and reagents were used as received from commercial suppliers without further purification unless stated otherwise.

${ }^{1} \mathrm{H}$ NMR spectra and ${ }^{13} \mathrm{C}$ NMR spectra were recorded at room temperature on a Bruker AV-300 spectrometer and a Bruker AV-400 spectrometer, respectively. ${ }^{1} \mathrm{H}$ NMR chemical shifts were referenced as follows: $\delta 7.26 \mathrm{ppm}$ for chloroform- $d\left(\mathrm{CDCl}_{3}\right), \delta 4.79 \mathrm{ppm}$ for deuterium oxide $\left(\mathrm{D}_{2} \mathrm{O}\right) .{ }^{13} \mathrm{CNMR}$ chemical shifts were referenced as follows: $\delta 77.16 \mathrm{ppm}$ for chloroform- $d$ $\left(\mathrm{CDCl}_{3}\right)$. Size exclusion chromatography (SEC) was carried outon a system composed of Waters 2414 Refractive Index Detector equipped with a series of connected size exclusion columns (1000 $\AA$ and $10000 \AA$ A Phenogel columns, $5 \mu \mathrm{m}, 300 \times 7.8 \mathrm{~mm}$, Phenomenex, Torrance, CA, USA). Polymer number-average weights $\left(M_{\mathrm{n}}\right)$ and polydispersity $(\nexists)$ were measured at $50^{\circ} \mathrm{C}$ in DMF (containing $0.02 \mathrm{M} \mathrm{LiBr}$ ) relative to polystyrene standards and a flow rate of $1 \mathrm{~mL} / \mathrm{min}$. Matrix-assisted laser desorption/ionization time-of-flight mass spectroscopy (MALDI-TOF/MS) measurements were performed on a Bruker autoflex III smart beam MALDI-TOF/TOF (Locality: Germany). ESI-MS condition was as follows: Instrument type: Waters Quattro Premier XE, Full Scan function type, $3.0 \mathrm{kV}$ Capillary, $20 \mathrm{~V}$ Cone, $110{ }^{\circ} \mathrm{C}$ Source Temperature, $80 \mathrm{~L} / \mathrm{Hr}$ Cone Gas Flow, $380{ }^{\circ} \mathrm{Cdesolvation}$ temperature and $600 \mathrm{~L} / \mathrm{Hr}$ Desolvation Gas Flow.

\section{Synthesis of dimethyl-protected cyclic lysine (DMCL)}

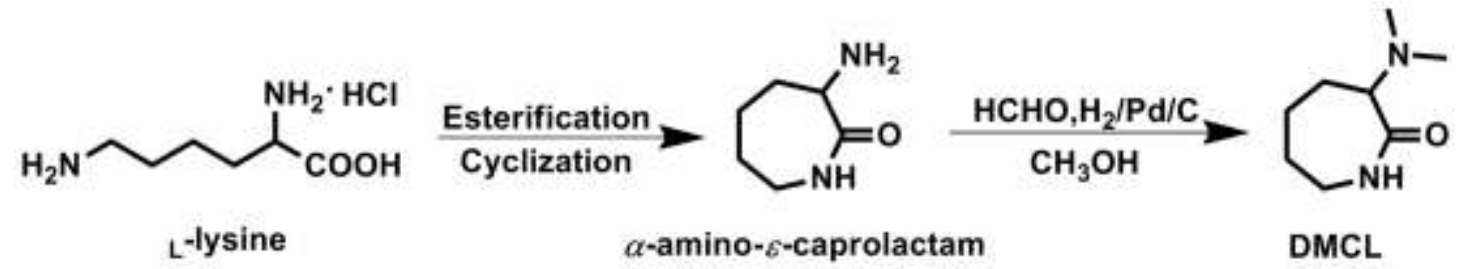

Scheme S1. Synthesis of dimethyl-protected cyclic lysine (DMCL).

The intermediate product $\alpha$-amino- $\varepsilon$-caprolactamwas prepared according to our previous work. ${ }^{[1]}$ Commercially available biorenewable ${ }_{\mathrm{L}}$-lysine monohydrochloride was used as a starting material, following by esterification with methanol in sulfuric acid, and cyclization in the presence of sodium hydroxide.

$10 \mathrm{~g}(78 \mathrm{mmol}) \alpha$-amino- $\varepsilon$-caprolactam was dissolved in methanol $(200 \mathrm{ml})$ in a round bottomed flask (500 mL). Formaldehyde (37\% aqueous solution, $14 \mathrm{ml}, \sim 172 \mathrm{mmol}$ ) and $\mathrm{Pd} / \mathrm{C}$ ( $10 \% \mathrm{Pd}$ on Carbon, $1 \mathrm{~g}$ ) were added to the solution. The mixture was stirred at room temperature for $36 \mathrm{~h}$ under a hydrogen atmosphere (atmospheric pressure, $\mathrm{H}_{2}$ balloon). The solution was then filtered through diatomaceous earth and concentrated under vacuum. The residue was dissolved in DCM $(100 \mathrm{ml})$ and washed with saturated $\mathrm{NaCl}$ solution $(3 \times 100 \mathrm{~mL})$. After evaporation of solvent in vacuo, the crude product was recrystallizedfrom ethyl acetate to obtain a white solid (yield, 80\%). ${ }^{1} \mathrm{H} \mathrm{NMR}\left(300 \mathrm{MHz} \mathrm{CDCl}_{3}\right) \delta 6.98(\mathrm{~s}, 1 \mathrm{H}), 3.53-3.46(\mathrm{~m}, 1 \mathrm{H}), 2.98-2.91(\mathrm{~m}, 1 \mathrm{H})$, 2.86-2.83 (t, 1H), $2.23(\mathrm{~s}, 6 \mathrm{H}), 1.91-1.79(\mathrm{~m}, 1 \mathrm{H}), 1.69-1.66(\mathrm{~m}, 2 \mathrm{H}), 1.58-1.42(\mathrm{~m}, 3 \mathrm{H}) .{ }^{13} \mathrm{C} \mathrm{NMR}$ $\left(100 \mathrm{MHz} \mathrm{CDCl}_{3}\right) \delta 178.07,69.76,42.48,41.27,29.52,26.81,25.42$. 
Synthesis of $N$-benzoyl- $\alpha$-dimethylamino- $\varepsilon$-caprolactam co-initiator (I).

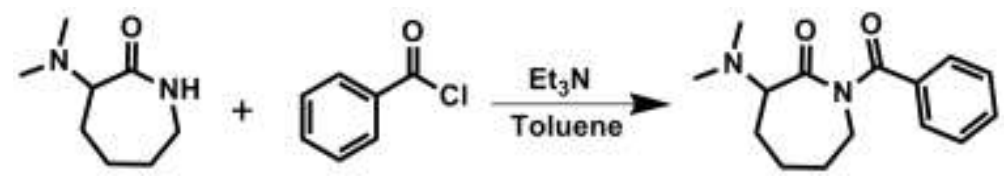

Dimethyl-protected cyclic lysine $(3.12 \mathrm{~g}, 20 \mathrm{mmol})$, triethylamine $(4 \mathrm{~mL}, 28 \mathrm{mmol})$ and benzoyl chloride $(3 \mathrm{~mL}, 24 \mathrm{mmol})$ was dissolved in toluene $(50 \mathrm{~mL})$ in a round bottomed flask $(100 \mathrm{~mL})$. After stirring at $115^{\circ} \mathrm{Cf}$ or $10 \mathrm{~h}$, the resulting mixture was concentrated under vacuum, and then $\mathrm{HCl}$ solution $(1 \mathrm{M}, 50 \mathrm{~mL})$ was added. The solution was extracted with DCM $(3 \times 50 \mathrm{~mL})$ and the solvent was removed at reduced pressure. The crude product was purified by column chromatography using petroleumether and ethyl acetate (10:1) as eluent to afford the product as a white solid (yield, 75\%). ${ }^{1} \mathrm{H}$ NMR $\left(300 \mathrm{MHz} \mathrm{CDCl}_{3}\right) \delta$ 7.55-7.35 (m, 5H), 4.54-4.47 (m, $\left.1 \mathrm{H}\right)$, 3.64-3.56 (m, 1H), 3.42-3.38 (m, 1H), $2.40(\mathrm{~s}, 6 \mathrm{H}), 2.06-1.98(\mathrm{~m}, 1 \mathrm{H}), 1.94-1.82(\mathrm{~m}, 3 \mathrm{H})$, 1.77-1.64 (m, 2H). ${ }^{13} \mathrm{C}$ NMR (100MHz CDCl 3 ) $\delta 176.88,174.79,136.96,131.47,128.23,127.75$, 69.70, 44.07, 41.81, 28.96, 28.86, 26.44.

\section{General polymerization procedure}

In a typical experiment, dimethyl-protected cyclic lysine $(156 \mathrm{mg})$ and $t-\mathrm{BuP}_{4}(50 \mu \mathrm{L}, 0.8 \mathrm{M}$ in hexane) were weighted and added to a flame-dried polymerization tube. The mixture was dried in a vacuum and purged with nitrogen at room temperature for 30 minutes to remove hexane. Then co-initiator I $(10.4 \mathrm{mg})$ was added and purged with nitrogen for three times. Than anhydrous DMAC $(200 \mu \mathrm{L})$ was added and the polymerization was allowed to proceed at $140{ }^{\circ} \mathrm{C}$ for $6 \mathrm{~h}$ under nitrogen atmosphere. After cool to room temperature, the polymerization was quenched by addition of $1 \mathrm{~mL}$ of benzoic acid/THF $(10 \mathrm{mg} / \mathrm{mL})$ and then precipitated in ethyl acetate/diethyl ether (1/1) to get the polymer (yield $\sim 80 \%$ ).

\section{General procedure for synthesis of poly ( $\varepsilon$-lysine) mimics}

In a typical experiment, poly(DMCL) $(2 \mathrm{~g})$ was dissolved in methanol $(40 \mathrm{ml})$ in a round bottomed flask $(100 \mathrm{~mL})$. Haloalkane $(3.64 \mathrm{~g}$ iodomethane or $2.79 \mathrm{~g}$ bromoethaneor $3.51 \mathrm{~g}$ bromobutane) was added to the solution. The reaction mixture was stirred at $40^{\circ} \mathrm{C}$ (for iodomethane and bromoethane or refluxed for bromobutane) for $40 \mathrm{~h}$ and then precipitated in ethyl acetate/diethyl ether (1/1) to get the poly( $\varepsilon$-lysine) mimics (yield 95\%).

\section{Thermodynamic study of the ROP}

The thermodynamic study of the ROP was performed according to the previous report. ${ }^{[2]}$ Dimethyl-protected cyclic lysine $(156 \mathrm{mg})$ and $t-\mathrm{BuP}_{4}(50 \mu \mathrm{L}, 0.8 \mathrm{M}$ in hexane) were weighted and added to a flame-dried polymerization tube. The mixture was dried in a vacuum and purged with nitrogen at room temperature for 30 minutes to remove hexane. Then, co-initiator I (10.4 mg) was added and purged with nitrogen for three times. Then, anhydrous DMAC $(200 \mu \mathrm{L})$ was added and the polymerization was allowed to proceed at different temperature $\left(80^{\circ} \mathrm{C}, 100{ }^{\circ} \mathrm{C}, 120^{\circ} \mathrm{C}\right.$, 
$\left.140{ }^{\circ} \mathrm{C}\right)$ for $24 \mathrm{~h}$ under nitrogen atmosphere. Then, the equilibrium monomer concentration $\left([\mathrm{M}]_{\mathrm{eq}}\right)$ was obtained by ${ }^{1} \mathrm{H}$ NMR analysis. The thermodynamic values were calculated by plotting the logarithm of the reciprocal of the equilibrium monomer concentration $\left(\ln \left(1 /[\mathrm{M}]_{\mathrm{eq}}\right)\right)$ with the reciprocal of temperature (1/T) based on the Van't Hoff equation.

\section{Antimicrobial assay}

The antimicrobial activities of the poly ( $\varepsilon$-lysine) and poly( $\varepsilon$-lysine) mimics were assessed by a modified microdilution assay, as previously reported. ${ }^{[3,4]}$ Bacteria were cultured in Muller Hinton (MH) broth at $37^{\circ} \mathrm{C}$ overnight, shaking at $150 \mathrm{rpm}$ to enter its log growth phase. $100 \mu \mathrm{L}$ of sample solution in MH broth at different concentrations from 50 to $800 \mu \mathrm{g} / \mathrm{mL}$ was filled into the wells of a 96-well culture plate by a two-fold dilution method. An equal volume of microbial suspension $\left(\sim 10^{5} \mathrm{CFU} / \mathrm{mL}\right)$ was added intoeach well.The 96-well platewas subsequently incubated at $37{ }^{\circ} \mathrm{C}$ for $20 \mathrm{~h}$ at $150 \mathrm{rpm}$. Positive control was without polymer and negative control without inoculum. Theoptical density (OD) values at $600 \mathrm{~nm}$ wavelength were collected by using a microplate reader. Each assay was performed in 3 replicates. The bacteriostasis rates were calculated as follows:

$$
\text { Bacteriostasis rates }(\%)=\frac{\text { (positive control ODs-sample ODs) }}{\text { (positive control ODs-negative control ODs) }} \times 100
$$

\section{Hemolysis assay}

The toxicity of the poly ( $\varepsilon$-lysine) and poly( $\varepsilon$-lysine) mimics against mammalian erythrocytes was tested using fresh rabbit red blood cells, as described in previously work. ${ }^{[5]}$ Briefly, fresh rabbit blood was diluted 25-fold in PBS buffer to achieve 4\% (in volume) of the blood cells. The poly ( $\varepsilon$-lysine) and poly( $\varepsilon$-lysine) mimics were dissolved in PBS at concentrations ranging from 12.5 to $1600 \mu \mathrm{g} / \mathrm{mL}$ by serial dilutions. Equal volumes of polymer solutions $(300 \mu \mathrm{L})$ were then mixed with the red blood cell suspension $(300 \mu \mathrm{L})$ in a1.5 mL microfuge tube. The mixtures were then incubated at $37{ }^{\circ} \mathrm{C}$ for $1 \mathrm{~h}$ to allow for the hemolysis process to take place. After that, the non-hemolysed red blood cells were separated by centrifugation at $1000 \mathrm{rpm}$ for $5 \mathrm{~min}$ and $100 \mu \mathrm{L}$ aliquots of the supernatant was pipetted into a 96-well microplate. The optical density (OD) values at $576 \mathrm{~nm}$ wavelength were collected by using a microplate reader. Two controls were provided in this assay: an untreated red blood cell suspension in PBS solution was used as the negative control; a solution containing red blood cells lysed with $1 \%$ Triton-X was used as the positive control. Each assay was performed in 3 replicates. The percentage of hemolysis was calculated as follows:

$$
\text { Hemolysis }(\%)=\frac{\text { (sample ODs-negative control ODs) }}{\text { (positive control ODs-negative control ODs) }} \times 100
$$

\section{Cytotoxicity assay}

The cytotoxicity of poly ( $\varepsilon$-lysine) and poly ( $\varepsilon$-lysine) mimicsagainst mouse fibroblast (L929) cells were determined by MTT assay. ${ }^{[6]}$ L929 cells were added into each well of a 96-well plate at a density of $10^{5}$ cells per well and incubated overnight in $100 \mu \mathrm{L}$ of Petri dish using Dulbecco's modified Eagle's medium (DMEM) at $37{ }^{\circ} \mathrm{C}, 5 \% \mathrm{CO}_{2}$. Then, the culture medium was replaced by 
fresh medium containing various concentrations of polymer ranging from 6.25 to $200 \mu \mathrm{g} / \mathrm{mL}$. After incubating at $37{ }^{\circ} \mathrm{C}, 5 \% \mathrm{CO}_{2}$ for another $48 \mathrm{~h}$, the medium was substituted with $100 \mu \mathrm{L}$ of fresh medium and $20 \mu \mathrm{L}$ MTT solution $(5 \mathrm{mg} / \mathrm{mL}$ in PBS).The plates were then maintained at $37{ }^{\circ} \mathrm{C}, 5 \% \mathrm{CO}_{2}$ for $4 \mathrm{~h}$. Subsequently, all medium was removed from each well and then $150 \mu \mathrm{L}$ DMSO was added to each well to dissolve the purple formazan crystals internalized by live cells. An untreated L929 cell suspension in DMEM solution was used as control. The optical density (OD) values at $570 \mathrm{~nm}$ wavelength were collected by using a microplate reader. Each assay was performed in 3 replicates. The percentage of cell viability was calculated as follows:

Cell viability $(\%)=\frac{\text { sample ODs }}{\text { control ODs }} \times 100$ 


\section{Supplementary Figures}

\section{A}
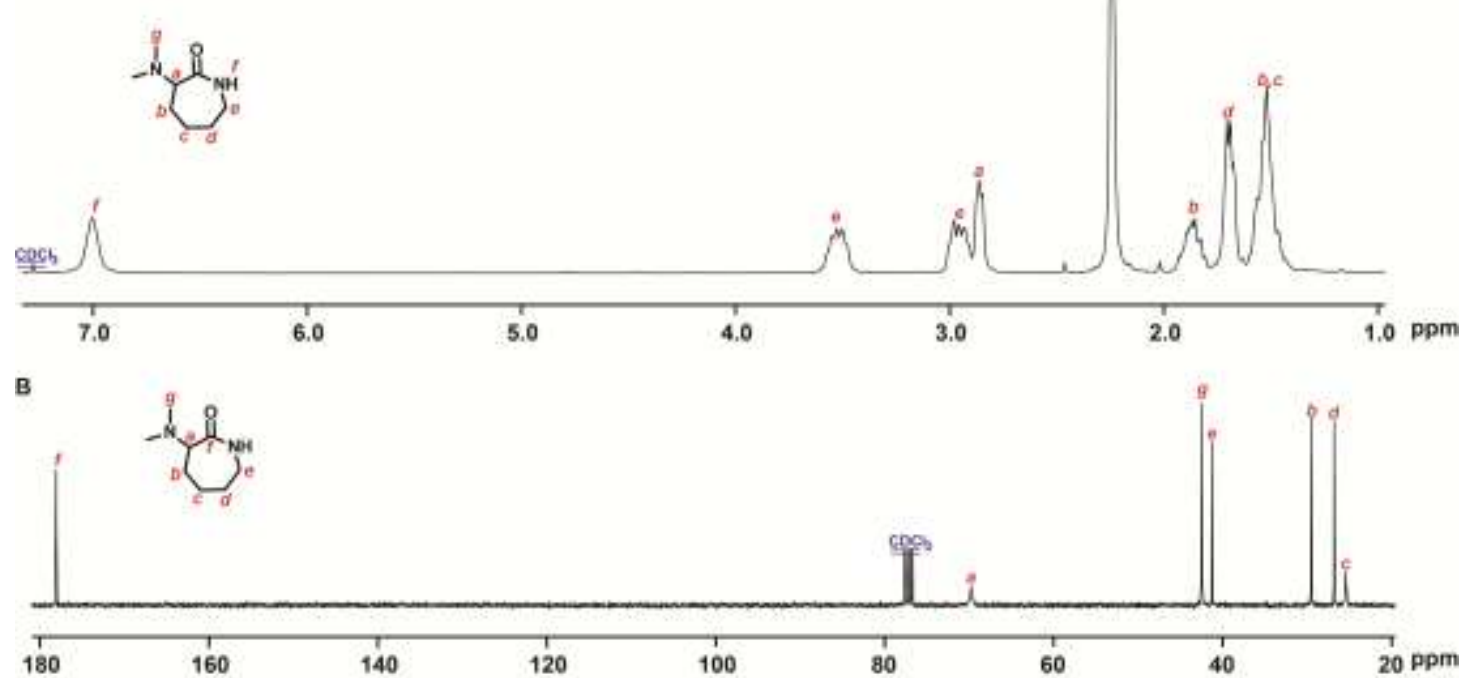

Figure S1. (A) ${ }^{1} \mathrm{H}$ NMR spectrum of dimethyl-protected cyclic lysine $\left(300 \mathrm{MHz}, \mathrm{CDCl}_{3}, 25^{\circ} \mathrm{C}\right)$. (B) ${ }^{13} \mathrm{C}$ NMR spectrum of dimethyl-protected cyclic lysine $\left(100 \mathrm{MHz}, \mathrm{CDCl}_{3}, 25^{\circ} \mathrm{C}\right)$. 


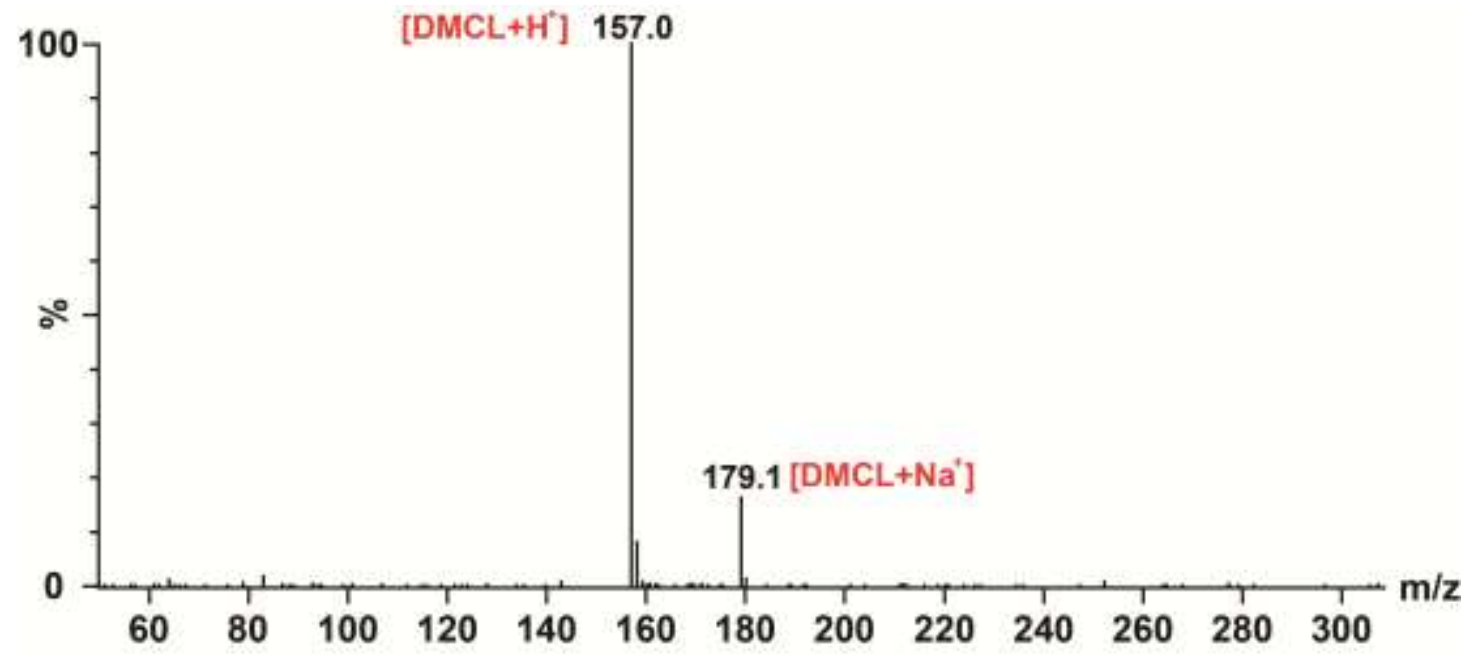

Figure S2. ESI-MS spectrum of dimethyl-protected cyclic lysine (DMCL). 
A
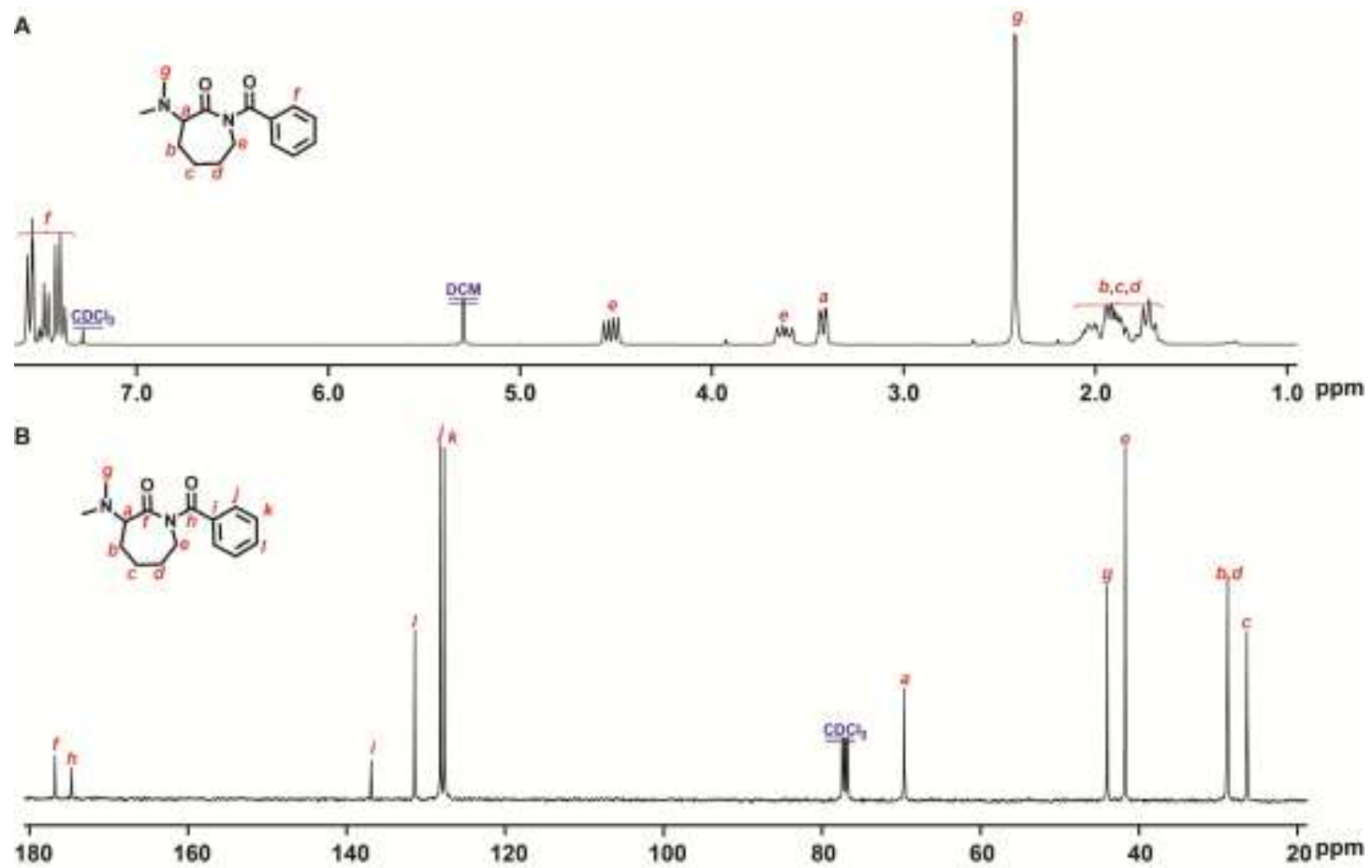

Figure S3. (A) ${ }^{1} \mathrm{H}$ NMR spectrum of $N$-benzoyl- $\alpha$-dimethylamino- $\varepsilon$-caprolactam co-initiator (I) $\left(300 \mathrm{MHz}, \mathrm{CDCl}_{3}, 25^{\circ} \mathrm{C}\right.$ ). (B) ${ }^{13} \mathrm{C}$ NMR spectrum of $N$-benzoyl- $\alpha$-dimethylamino- $\varepsilon$-caprolactam co-initiator (I) $\left(100 \mathrm{MHz}, \mathrm{CDCl}_{3}, 25^{\circ} \mathrm{C}\right)$. 


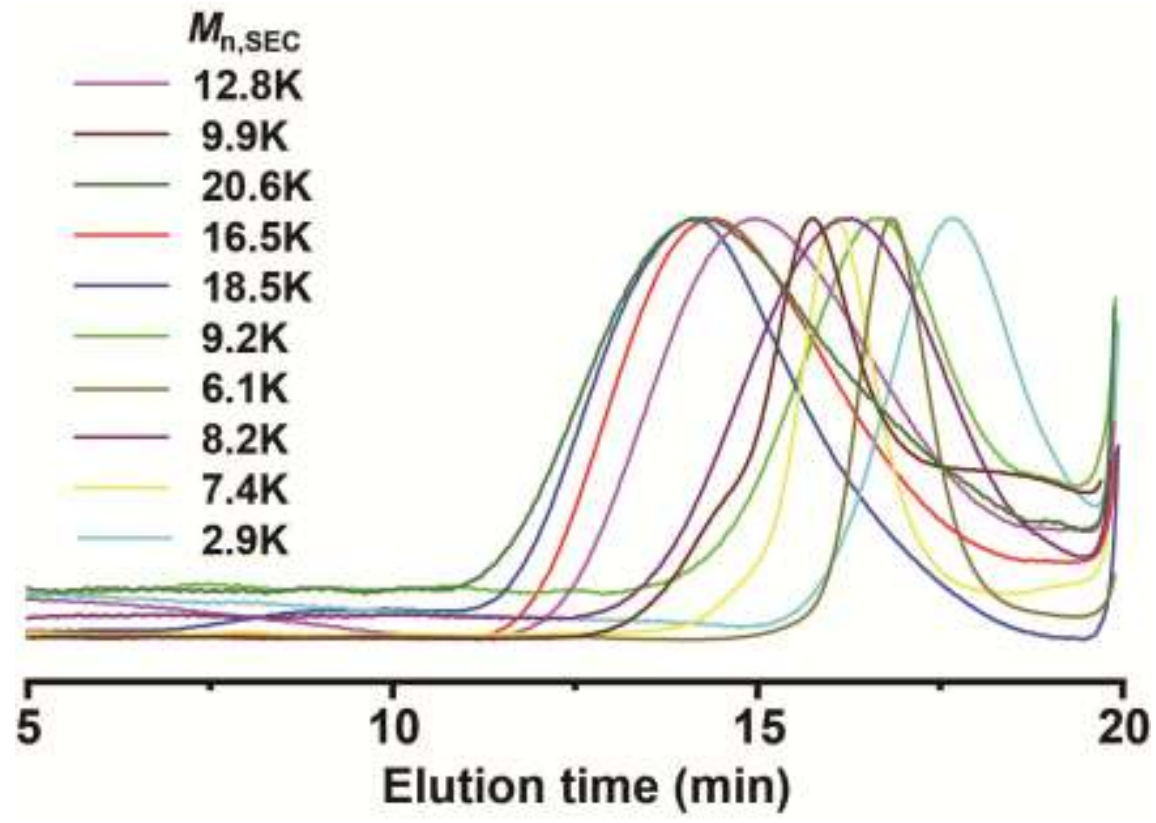

Figure S4. Original SEC traces in Table 1. 
A)

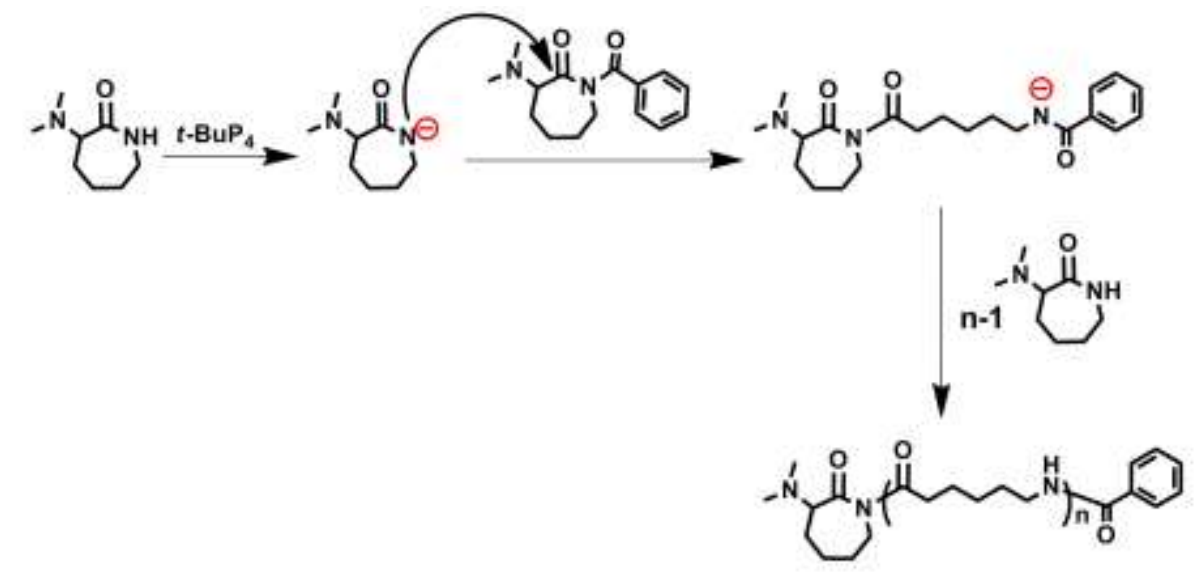

B)

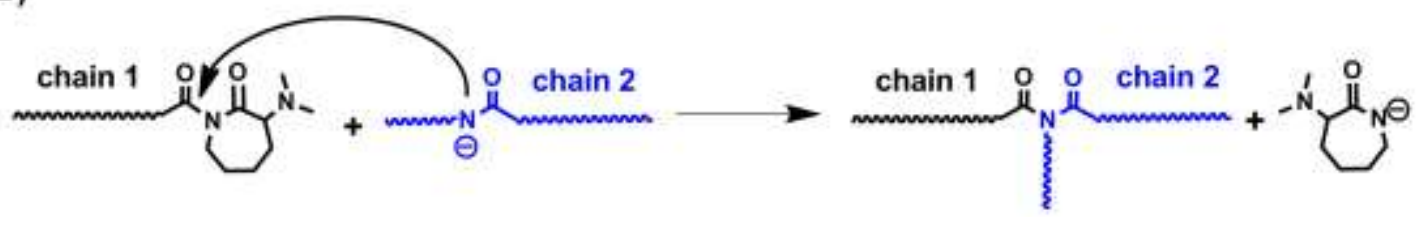

Figure S5. A) Proposed mechanism for the ROP of dimethyl protected cyclic lysine monomer by $t-\mathrm{BuP}_{4}$ in the presence of co-initiator. B) Possible transamidation reaction between polymer chains. 

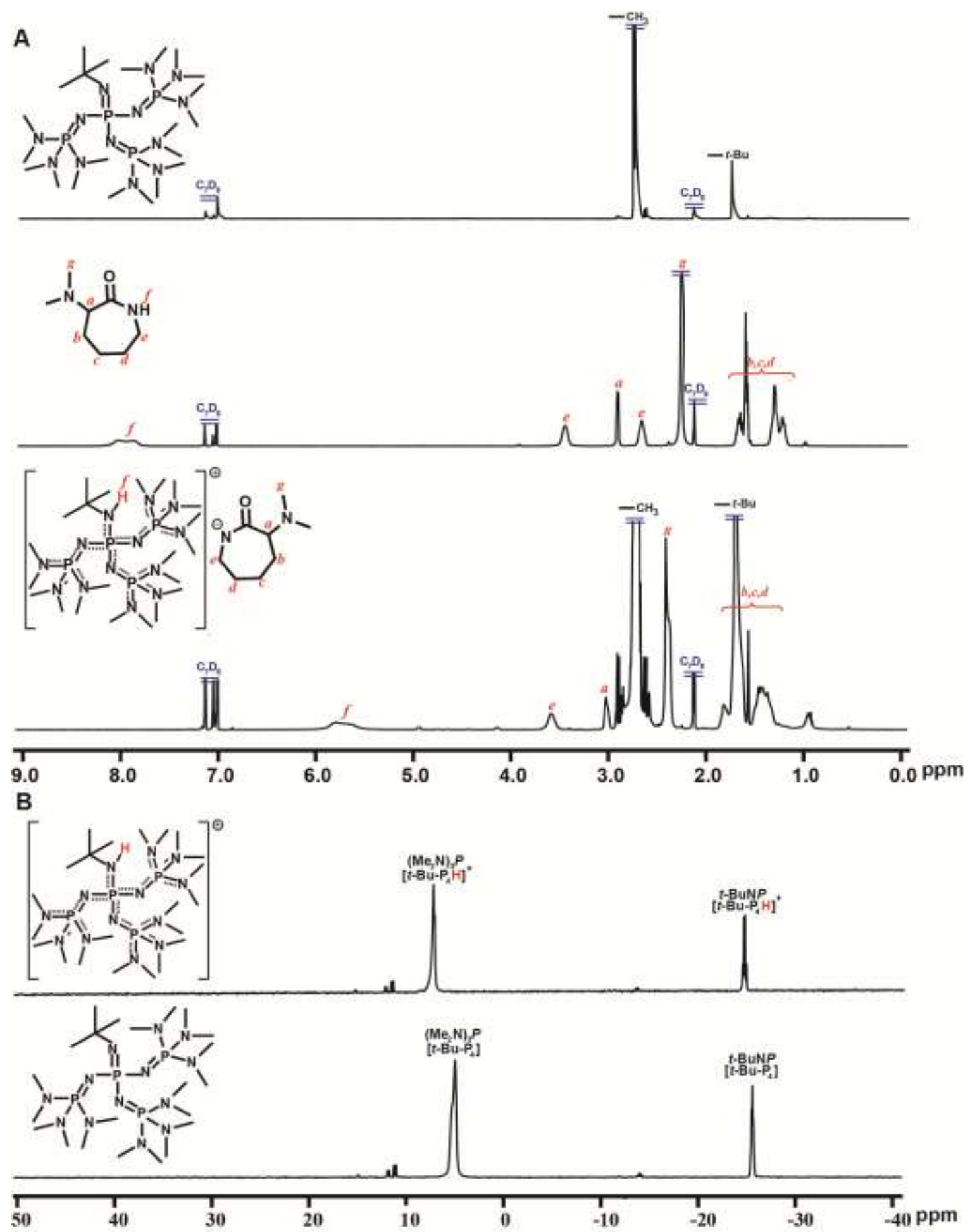

Figure S6. (A) ${ }^{1} \mathrm{H}$ NMR spectra (toluene- $d_{8}, 25{ }^{\circ} \mathrm{C}$ ) of the reaction between $t$ - $\mathrm{BuP}_{4}$ and DMCL (1:1). (B) ${ }^{31} \mathrm{P}$ NMR spectra (toluene- $d_{8}, 25^{\circ} \mathrm{C}$ ) of the reaction between $t$ - $\mathrm{BuP}_{4}$ and DMCL (1:1). 


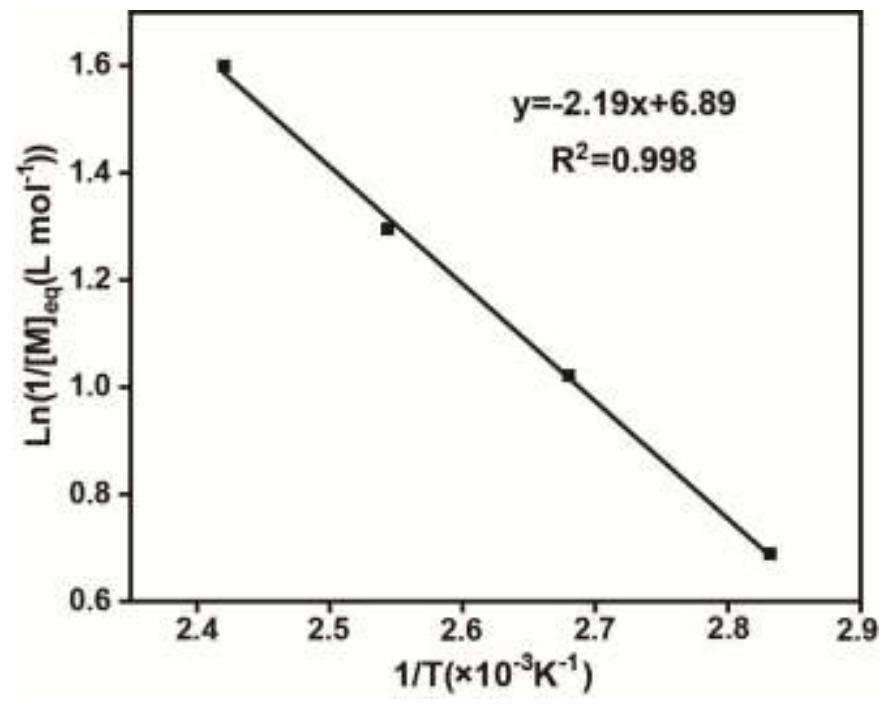

$\operatorname{Ln}\left(1 /[\mathrm{M}]_{\mathrm{eq}}\right)=-\Delta H_{\mathrm{P}}^{\circ} / \mathrm{RT}+\Delta S_{\mathrm{P}}^{\circ} / \mathrm{R}$

Figure S7. Van't Hoff plot of the $t$ - $\mathrm{BuP}_{4}$-catalyzed ROP of DMCL. 

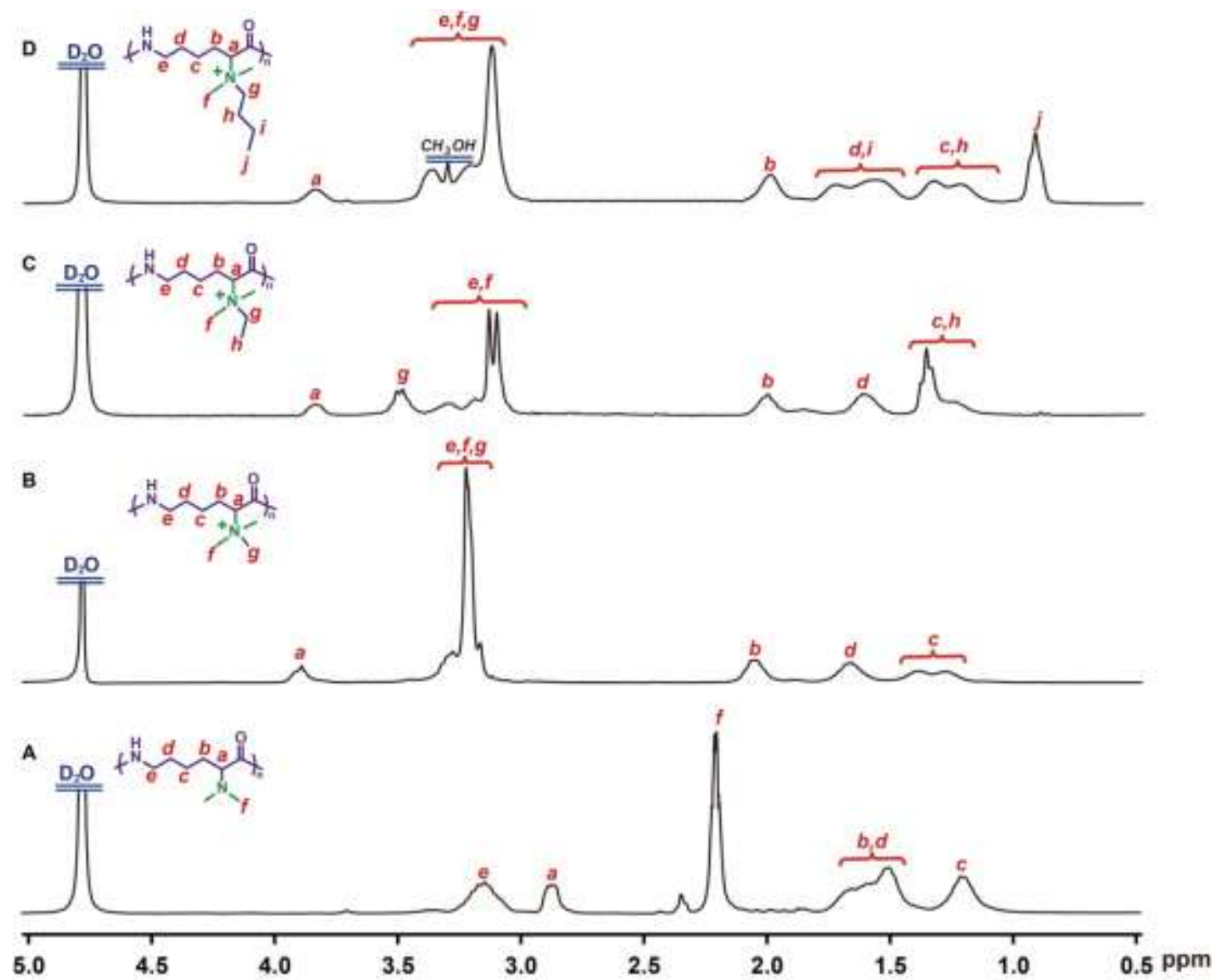

Figure S8. ${ }^{1} \mathrm{H}$ NMR spectrum of poly ( $\varepsilon$-lysine) and poly ( $\varepsilon$-lysine) mimics $\left(300 \mathrm{MHz}, \mathrm{D}_{2} \mathrm{O}, 25\right.$ ${ }^{\circ} \mathrm{C}$ ). (A) Poly(DMCL). (B) $\varepsilon$-PL mimics P2. (C) $\varepsilon$-PL mimics P3. (D) $\varepsilon$-PL mimics P4. 

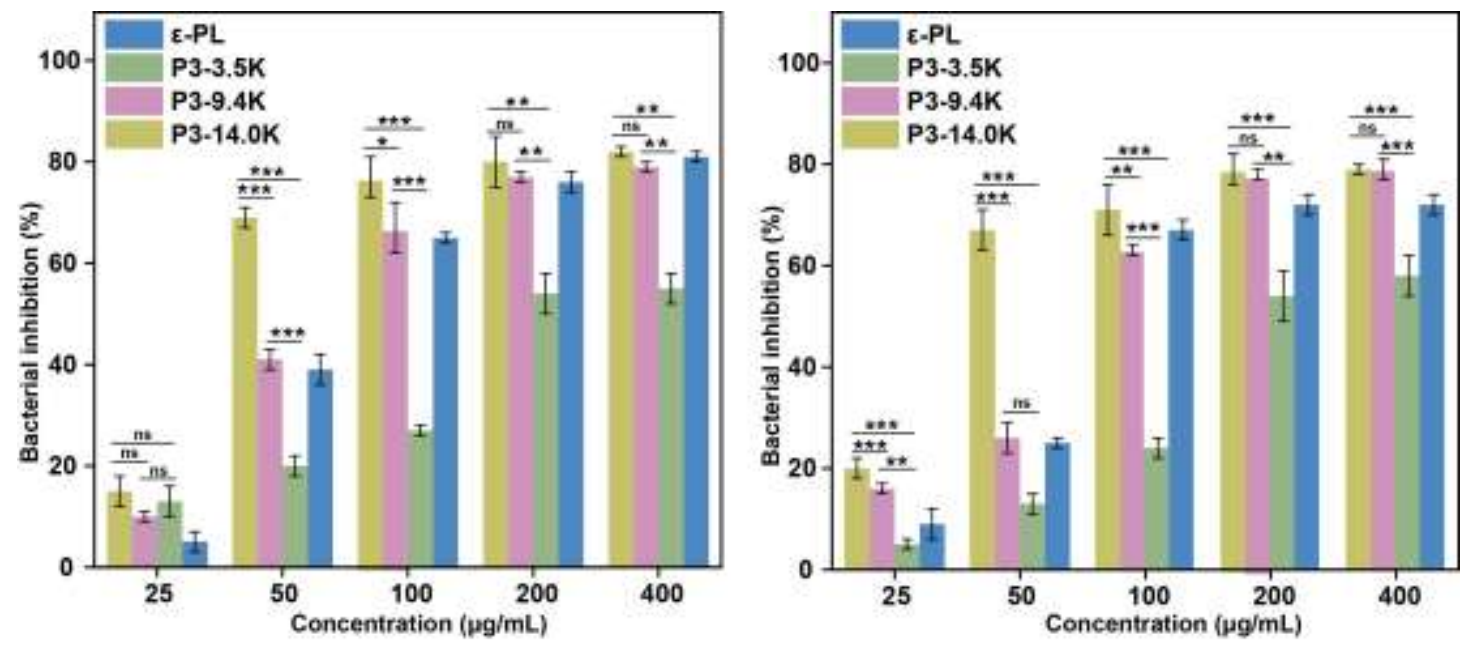

Figure S9 Antimicrobial activities of $\mathrm{P} 3$ with different molecular weight against A) E.coli and B) S.aureus. The error bars are the standard deviations of three evaluations. Statistical significance performed with Graph Pad Prism 8 using a one-way classification of ANOVA followed by Brown-Forsythe and Welch ANOVA tests, ${ }^{*} p<0.05, * * p<0.01, * * * p<0.001$ ns: no significance.

P3-3.5K, P3-9.4K and P3-14.0K mean that the polymer molecular weight was $3.5 \mathrm{kDa}, 9.4 \mathrm{kDa}$ and $14.0 \mathrm{kD}$, a respectively before quaternization with ethane bromide. 


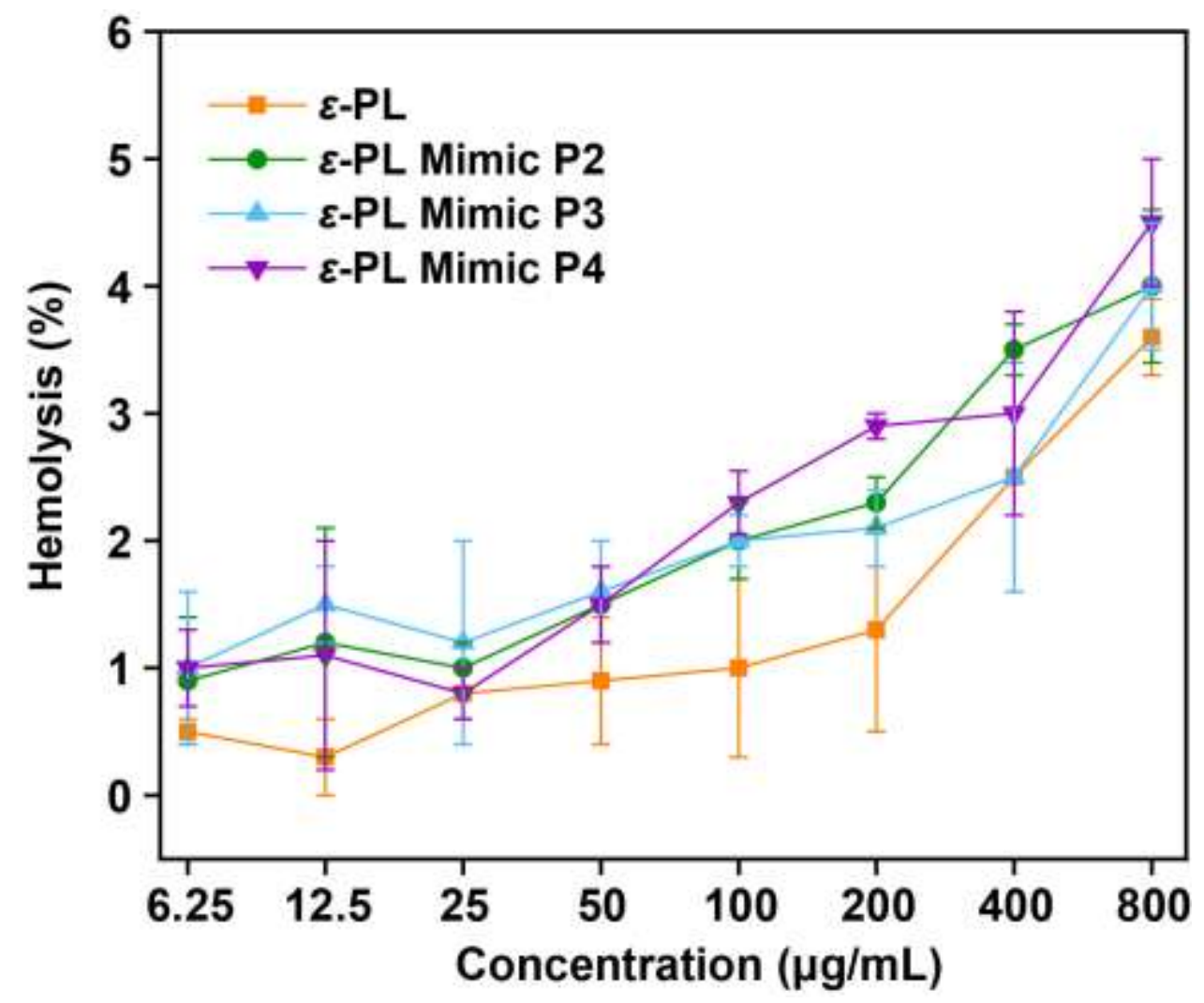

Figure S10. Hemolysis activities of poly ( $\varepsilon$-lysine) and poly ( $\varepsilon$-lysine) mimics.The error bars are the standard deviations of three evaluations. 


\section{Supplementary Tables}

Table S1. Bacteriostasis rates of $\varepsilon$-PL and $\varepsilon$-PL mimics against E.coli and S.aureus at various concentrations.

\begin{tabular}{|c|c|c|c|c|c|}
\hline \multirow{2}{*}{ polymer } & $\varepsilon-\mathrm{PL}$ & $\mathrm{P} 2$ & $\mathrm{P} 3$ & $\mathrm{P} 4$ \\
\hline \multirow{3}{*}{$400 \mu \mathrm{g} / \mathrm{ml}$} & E.coli & $81 \% \pm 4 \%$ & $80 \% \pm 3 \%$ & $83 \% \pm 2 \%$ & $83 \% \pm 3 \%$ \\
\cline { 2 - 6 } & S.aureus & $75 \% \pm 2 \%$ & $74 \% \pm 2 \%$ & $78 \% \pm 2 \%$ & $71 \% \pm 2 \%$ \\
\hline \multirow{3}{*}{$200 \mu \mathrm{g} / \mathrm{ml}$} & E.coli & $81 \% \pm 2 \%$ & $80 \% \pm 5 \%$ & $83 \% \pm 5 \%$ & $63 \% \pm 5 \%$ \\
\cline { 2 - 6 } & S.aureus & $72 \% \pm 3 \%$ & $73 \% \pm 5 \%$ & $76 \% \pm 3 \%$ & $58 \% \pm 3 \%$ \\
\hline \multirow{3}{*}{$100 \mu \mathrm{g} / \mathrm{ml}$} & E.coli & $76 \% \pm 4 \%$ & $72 \% \pm 4 \%$ & $83 \% \pm 4 \%$ & $23 \% \pm 4 \%$ \\
\cline { 2 - 6 } & S.aureus & $67 \% \pm 5 \%$ & $66 \% \pm 4 \%$ & $75 \% \pm 2 \%$ & $26 \% \pm 4 \%$ \\
\hline \multirow{3}{*}{$50 \mu \mathrm{g} / \mathrm{ml}$} & E.coli & $37 \% \pm 5 \%$ & $34 \% \pm 2 \%$ & $31 \% \pm 3 \%$ & $11 \% \pm 4 \%$ \\
\cline { 2 - 6 } & S.aureus & $18 \% \pm 1 \%$ & $17 \% \pm 2 \%$ & $33 \% \pm 4 \%$ & $16 \% \pm 3 \%$ \\
\hline \multirow{2}{*}{$25 \mu \mathrm{g} / \mathrm{ml}$} & E.coli & $18 \% \pm 3 \%$ & $10 \% \pm 4 \%$ & $14 \% \pm 4 \%$ & $6 \% \pm 1 \%$ \\
\cline { 2 - 6 } & S.aureus & $2 \% \pm 1 \%$ & $5 \% \pm 2 \%$ & $3 \% \pm 1 \%$ & $3 \% \pm 1 \%$ \\
\hline \multirow{2}{*}{ MIC50 } & E.coli & $100 \mu \mathrm{g} / \mathrm{ml}$ & $100 \mu \mathrm{g} / \mathrm{ml}$ & $100 \mu \mathrm{g} / \mathrm{ml}$ & $200 \mu \mathrm{g} / \mathrm{ml}$ \\
\cline { 2 - 6 } & S.aureus & $100 \mu \mathrm{g} / \mathrm{ml}$ & $100 \mu \mathrm{g} / \mathrm{ml}$ & $100 \mu \mathrm{g} / \mathrm{ml}$ & $200 \mu \mathrm{gg} / \mathrm{ml}$ \\
\hline
\end{tabular}

The MIC50 values represent the lowest antimicrobial concentration leading to $>50 \%$ bacteriostasis rates. $^{[7]}$ 
Table S2. Hemolysis rates of $\varepsilon$-PL and $\varepsilon$-PL mimics against rabbit red blood cells at various concentrations.

\begin{tabular}{|c|c|c|c|c|}
\hline polymer & $\varepsilon-\mathrm{PL}$ & $\mathrm{P} 2$ & $\mathrm{P} 3$ & $\mathrm{P} 4$ \\
\hline $800 \mu \mathrm{g} / \mathrm{ml}$ & $3.6 \% \pm 0.3 \%$ & $4 \% \pm 0.6 \%$ & $4 \% \pm 0.5 \%$ & $4.5 \% \pm 0.5 \%$ \\
\hline $400 \mu \mathrm{g} / \mathrm{ml}$ & $2.5 \% \pm 0.9 \%$ & $3.5 \% \pm 0.2 \%$ & $2.5 \% \pm 0.9 \%$ & $3 \% \pm 0.8 \%$ \\
\hline $200 \mu \mathrm{g} / \mathrm{ml}$ & $1.3 \% \pm 0.8 \%$ & $2.3 \% \pm 0.2 \%$ & $2.1 \% \pm 0.3 \%$ & $2.9 \% \pm 0.1 \%$ \\
\hline $100 \mu \mathrm{g} / \mathrm{ml}$ & $1 \% \pm 0.7 \%$ & $2 \% \pm 0.3 \%$ & $2 \% \pm 0.2 \%$ & $2.3 \% \pm 0.3 \%$ \\
\hline $50 \mu \mathrm{g} / \mathrm{ml}$ & $0.9 \% \pm 0.5 \%$ & $1.5 \% \pm 0.3 \%$ & $1.6 \% \pm 0.4 \%$ & $1.5 \% \pm 0.3 \%$ \\
\hline $25 \mu \mathrm{g} / \mathrm{ml}$ & $0.8 \% \pm 0.2 \%$ & $1 \% \pm 0.2 \%$ & $1.2 \% \pm 0.8 \%$ & $0.8 \% \pm 0.2 \%$ \\
\hline $12.5 \mu \mathrm{g} / \mathrm{ml}$ & $0.3 \% \pm 0.3 \%$ & $1.2 \% \pm 0.9 \%$ & $1.5 \% \pm 0.3 \%$ & $1.1 \% \pm 0.9 \%$ \\
\hline $6.25 \mu \mathrm{g} / \mathrm{ml}$ & $0.5 \% \pm 0.1 \%$ & $0.9 \% \pm 0.5 \%$ & $1 \% \pm 0.6 \%$ & $1 \% \pm 0.3 \%$ \\
\hline $\mathrm{MHC} 50$ & $>800 \mu \mathrm{g} / \mathrm{ml}$ & $>800 \mu \mathrm{g} / \mathrm{ml}$ & $>800 \mu \mathrm{g} / \mathrm{ml}$ & $>800 \mu \mathrm{g} / \mathrm{ml}$ \\
\hline
\end{tabular}


Table S3. Bacteriostasis rates of $\varepsilon$-PL and P3 with different molecular weight against E.coli and S.aureus at various concentrations.

\begin{tabular}{|c|c|c|c|c|c|}
\hline \multirow{2}{*}{ polymer } & $\varepsilon-\mathrm{PL}$ & $\mathrm{P} 3-3.5 \mathrm{~K}^{a}$ & $\mathrm{P} 3-9.4 \mathrm{~K}^{a}$ & $\mathrm{P}^{2}-14.0 \mathrm{~K}^{a}$ \\
\hline \multirow{3}{*}{$400 \mu \mathrm{g} / \mathrm{ml}$} & E.coli & $81 \% \pm 1 \%$ & $55 \% \pm 3 \%$ & $79 \% \pm 1 \%$ & $82 \% \pm 1 \%$ \\
\cline { 2 - 6 } & S.aureus & $72 \% \pm 2 \%$ & $58 \% \pm 4 \%$ & $79 \% \pm 2 \%$ & $79 \% \pm 1 \%$ \\
\hline \multirow{3}{*}{$200 \mu \mathrm{g} / \mathrm{ml}$} & E.coli & $76 \% \pm 2 \%$ & $54 \% \pm 4 \%$ & $77 \% \pm 1 \%$ & $80 \% \pm 5 \%$ \\
\cline { 2 - 6 } & S.aureus & $72 \% \pm 2 \%$ & $54 \% \pm 5 \%$ & $78 \% \pm 1 \%$ & $79 \% \pm 3 \%$ \\
\hline \multirow{3}{*}{$100 \mu \mathrm{g} / \mathrm{ml}$} & E.coli & $65 \% \pm 1 \%$ & $27 \% \pm 1 \%$ & $67 \% \pm 5 \%$ & $77 \% \pm 4 \%$ \\
\cline { 2 - 6 } & S.aureus & $67 \% \pm 2 \%$ & $24 \% \pm 2 \%$ & $63 \% \pm 1 \%$ & $71 \% \pm 5 \%$ \\
\hline \multirow{3}{*}{$50 \mu \mathrm{g} / \mathrm{ml}$} & E.coli & $39 \% \pm 3 \%$ & $20 \% \pm 2 \%$ & $41 \% \pm 2 \%$ & $69 \% \pm 2 \%$ \\
\cline { 2 - 6 } & S.aureus & $25 \% \pm 1 \%$ & $13 \% \pm 2 \%$ & $26 \% \pm 3 \%$ & $67 \% \pm 4 \%$ \\
\hline \multirow{2}{*}{$25 \mu \mathrm{g} / \mathrm{ml}$} & E.coli & $5 \% \pm 2 \%$ & $13 \% \pm 3 \%$ & $10 \% \pm 1 \%$ & $15 \% \pm 3 \%$ \\
\cline { 2 - 6 } & S.aureus & $9 \% \pm 3 \%$ & $5 \% \pm 1 \%$ & $16 \% \pm 1 \%$ & $20 \% \pm 2 \%$ \\
\hline
\end{tabular}

${ }^{a} \mathrm{P} 3-3.5 \mathrm{~K}, \mathrm{P} 3-9.4 \mathrm{~K}$ and $\mathrm{P} 3-14.0 \mathrm{~K}$ mean that the polymer molecular weight was $3.5 \mathrm{kDa}, 9.4 \mathrm{kDa}$ and $14.0 \mathrm{kDa}$ respectively before quaternization with ethane bromide. 
Table S4. Biocompatibility of $\varepsilon$-PL and $\varepsilon$-PL mimics with mouse fibroblast (L929) cells at various concentrations.

\begin{tabular}{|c|c|c|c|c|}
\hline polymer & $\varepsilon-\mathrm{PL}$ & $\mathrm{P} 2$ & $\mathrm{P} 3$ & $\mathrm{P} 4$ \\
\hline $200 \mu \mathrm{g} / \mathrm{ml}$ & $90 \% \pm 6 \%$ & $89 \% \pm 7 \%$ & $82 \% \pm 7 \%$ & $94 \% \pm 9 \%$ \\
\hline $100 \mu \mathrm{g} / \mathrm{ml}$ & $88 \% \pm 7 \%$ & $90 \% \pm 7 \%$ & $83 \% \pm 5 \%$ & $92 \% \pm 8 \%$ \\
\hline $50 \mu \mathrm{g} / \mathrm{ml}$ & $91 \% \pm 6 \%$ & $92 \% \pm 9 \%$ & $86 \% \pm 8 \%$ & $93 \% \pm 9 \%$ \\
\hline $25 \mu \mathrm{g} / \mathrm{ml}$ & $89 \% \pm 2 \%$ & $95 \% \pm 4 \%$ & $89 \% \pm 5 \%$ & $95 \% \pm 8 \%$ \\
\hline $12.5 \mu \mathrm{g} / \mathrm{ml}$ & $93 \% \pm 5 \%$ & $93 \% \pm 8 \%$ & $90 \% \pm 8 \%$ & $96 \% \pm 6 \%$ \\
\hline $6.25 \mu \mathrm{g} / \mathrm{ml}$ & $95 \% \pm 4 \%$ & $95 \% \pm 7 \%$ & $95 \% \pm 8 \%$ & $98 \% \pm 7 \%$ \\
\hline
\end{tabular}

\section{References}

(1) Y. Tao, X. Chen, J. Fan, S. Wang, C. Xiao, F. Cui, Y. Li, Z. Bian, X. Chen, X. Wang, Chemical Science 2015,5, 6385-6391.

(2) J. Yuan, W. Xiong, X. Zhou, Y. Zhang, D. Shi, Z. Li, H. Lv, Journal of the American Chemical Society 2019, 141, 4928-4935.

(3) W. Chin, C. Yang, V. W. L. Ng, Y. Huang, J. Cheng, Y. W. Tong, D. J. Coady, W. Fan, J. L. Hedrick, Y. Y. Yang, Macromolecules 2013, 46, 8797-8807.

(4) Q. Zhang, P. Ma, J. Xie, S. Zhang, X. Xiao, Z. Qiao, N. Shao, M. Zhou, W. Zhang, C. Dai, Y. Qian, F. Qi, R. Liu, Biomaterials Science 2019, 7, 2144-2151.

(5) M. Xiong, M. W. Lee, R. A. Mansbach, Z. Song, Y. Bao, R. M. Peek Jr., C. Yao, L. Chen, A. L. Ferguson, G. C. L. Wong, J. Cheng, PNAS 2015, 112, 13155-13160.

(6) N. H. Park, W. Cheng, F. Lai, C. Yang, P. F. Sessions, B. Periaswamy, C. W. Chu, S. Bianco, S. Liu, S. Venkataraman, Q. Chen, Y. Y. Yang, J. L. Hedrick, Journal of the American Chemical Society 2018, 140, 4244-4252.

(7) Y. K. Cheong, M. P. Arce, A. Benito, D. Chen,N. L. Crisóstomo, L. V. Kerai, G. Rodríguez, J. L. Valverde ,M. Vadalia, A. Cerpa-Naranjo, G. Ren, Nanomaterials 2020, 10, 819. 